$\mathrm{Hal}: 49-53$

\title{
PENERAPAN MODEL PEMBELAJARAN SIKLUS BELAJAR (LEARNING CYCLE) DALAM MENINGKATKAN HASIL BELAJAR SISWA PADA MATA PELAJARAN IPA KELAS VIII SMP N 1 SILANGKITANG
}

\author{
Risma Delima Harahap \\ Dosen Program Studi Pendidikan Biologi, STKIP Labuhan Batu \\ *Email:rismadelimaharahap@gmail.com
}

Diterima Oktober 2018 dan Disetujui Desember 2018

\begin{abstract}
ABSTRAK
Penelitian ini bertujuan untuk mengungkapkan penerapan model pembelajaran siklus belajar (learning cycle) dalam meningkatkan hasil belajar siswa pada mata pelajaran IPA kelas VIII SMP N 1 Silangkitang. Penelitian yang digunakan yaitu pendekatan kualitatif jenis penelitian tindakan kelas. Subjek yang digunakan berjumlah 30 orang siswa SMP N 1 Silangkitang. Temuan penelitian ini adalah penerapan model pembelajaran siklus belajar (learning cycle) dapat meningkatkan hasil belajar siswa pada mata pelajaran IPA kelas VIII SMP N 1 Silangkitang, terlihat pada pelaksanaan siklus I nilai rata-rata siswa sebesar 61,50 , dan pada siklus II nilai rata-rata siswa meningkat sebesar 79.83. Model pembelajaran siklus belajar (learning cycle) dapat meningkatkan hasil belajar siswa pada mata pelajaran IPA kelas VIII SMP N 1 Silangkitang dan dapat diterapkan dalam proses belajar mengajar di sekolah.

Kata Kunci: Hasil Belajar, Penerapan Model Pembelajaran Siklus Belajar
\end{abstract}




\section{PENDAHULUAN}

Perkembangan hidup manusia dilakukan dengan berbagai proses yang salah satunya di mulai dengan belajar, manusia melakukan perubahan-perubahan kualitatif individu sehingga tingkah lakunya berkembang semua, aktivitas dan prestasi hidup tidak lain adalah hasil belajar. Bukti adanya bahwa seseorang telah melakukan proses belajar adalah terjadinya perubahan tingkah laku pada orang tersebut, misalnya dari tidak tahu menjadi tahu, dan dari tidak mengerti menjadi mengerti. Untuk mengetahui hasil belajar seseorang adalah melihat kemampuan-kemampuan yang dimiliki siswa setelah menerima pengalaman belajar. Hasil belajar digunakan oleh guru sebagai ukuran atau kreteria dalam mencapai suatu tujuan pendidikan. Hal ini dapat tercapai apabila siswa sudah memahami belajar diiringi dengan perubahan tingkah laku yang lebih baik lagi. Salah satu materi pelajaran yaitu IImu Pengetahuan Alam (IPA) adalah sebagai disiplin ilmu dan penerapannya dalam masyarakat membuat pendidikan IPA menjadi penting. Samatowa mengutip pendapat Hendro Darmojo yang menyatakan IPA adalah pengetahuan yang rasional dan objektif tentang alam semesta dengan segala isinya. Selain itu Samotowa juga mengutip pendapat Nash yang menyatakan bahwa materi pelajaran IPA adalah suatu cara, teknik atau metode untuk mengamati alam dan gejalanya, Nash juga menjelaskan bahwa materi di pelajaran IPA yang mengamati dunia ini bersifat aktual, analisis, lengkap dan sempurna dan cermat, serta menghubungkannya atara suatu fenomena dengan fenomena lain, sehingga keseluruhannya membentuk suatu perspektif yang baru tentang objek yang diamati.

Pembelajaran IPA melatih anak berpikir kritis dan objektif. Pengetahuan yang benar adalah pengetahuan yang dibenarkan menurut tolak ukur kebenaran ilmu, yang rasional (masuk akal dan diterima oleh akal sehat) dan objektif (sesuai dengan pengalaman pengamatan melalui panca indera). Model pembelajaran yang cocok untuk anak indonesia adalah belajar melalui pengalaman langsung (learning by doing). Rendahnya aktivitas belajar siswa di atas tidak akan terjadi jika adanya upaya-upaya sekolah selalu memperhatikan aktifitas belajar siswa dengan cara memberikan bimbingan, arahan, serta memfasilitasi sarana dan prasarana sebagai wujud perhatian dan komunikasi kepada siswa. Siswa tentu akan giat belajar jika mendapatkan perhatian, dengan adanya metode dan sarana prasarana yag mendukung siswa untuk belajar secara langsung, apalagi pelajaran IPA adalah belajar melalui pengalaman langsung. Rendahnya aktivitas belajar siswa besar kemungkinan disebabkan oleh kurang maksimalnya upaya guru dalam memberikan model pembelajaran yang baik kepada siswa.

Cara belajar yang baik adalah jika melibatkan siswa secara langsung dalam kegiatan belajar mengajar, guru hanya sebagai Mediator, Fasilitator, Motivator, dan Evaluator. Salah satu jenis pembelajaran yang melibatkan siswa secara langsung dalam proses pembelajaran adalah Model Pembelajaran Siklus Belajar (Learning Cycle). Pada pembelajaran ini guru memberikan materi secara garis besar, selanjutnya siswa memperdalam sendiri materi-materi tersebut dengan membentuk atau menyusun konsep-konsep yang ada di dalam pikirannya. Dalam model pembelajaran ini siswa ditugaskan untuk mendefenisikan suatu materi tidak berdasarkan teks hafalan, melainkan memahami makna materi tersebut.

\section{METODE PENELITIAN}

\section{Pendekatan dan Jenis Penelitian}

Pendekatan yang digunakan adalah pendekatan kualitatif. Jenis penelitian yang akan dilaksanakan adalah penelitian tindakan kelas (action research classroom).

\section{Tempat dan Waktu Penelitian}

Penelitian ini dilaksanakan di SMP N 1 Silangkitang Kabupaten Labuhan Batu. Waktu penelitian dilaksanakan dibulan juli 2017.

\section{Subjek penelitian}

Subjek penelitian ini adalah siswa kelas VIII SMP N 1 Silangkitang yang berjumlah 30 orang.

\section{Teknik Analisa Data}

Teknik analisa data dilakukan dengan analisis kualitatif.

1. Reduksi Data

Proses reduksi data yang dilakukan dengan cara proses menyeleksi, menyederhanakan, meringkas dan mengubah bentuk data mentah yang ada dari lapangan.

2. Deskripsi Data

Data hasil reduksi dari lapangan dipaparkan berdasarkan fakta yang ada di lapangan.

a. Menganalisis data, yaitu menginterpretasi data hasil temuan penelitian di lapangan dengan cara membandingkan antara kajian teoritis dengan kenyataan yang ada di lapangan.

b. Penarikan kesimpulan, adalah disesuaikan dengan tujuan penelitian dan berdasarkan hasil penelitian yang telah dilakukan.

Untuk analisis tingkat keberhasilan atau persentase ketuntasan belajar siswa setelah proses belajar mengajar berlangsung pada tiap siklusnya, dilakukan dengan cara memberikan evaluasi_berupa 
$\mathrm{Hal}: 49-53$

soal tes tertulis berbentuk multiple choise pada setiap akhir siklus. Analisis ini dihitung dengan menggunakan statistik sederhana sebagai berikut:

1. Penilaian Tugas dan Tes

Menjumlahkan nilai yang diperoleh siswa, selanjutnya dibagi dengan jumlah siswa kelas VIII tersebut sehingga diperoleh nilai rata-rata. Nilai rata-rata ini didapat dengan menggunakan rumus:

$$
\mathrm{X}=\frac{\Sigma \mathrm{X}}{\Sigma \mathrm{N}}
$$

Keterangan:

$X=$ nilai rata-rata

$\Sigma X=$ jumlah semua nilai siswa

$\Sigma \mathrm{N}=$ jumlah siswa

\section{Penilaian untuk Ketuntasan Belajar}

Kategori ketuntasan belajar yang digunakan yaitu secara perorangan dan secara klasikal.

\section{G. Teknik Penjamin Keabsahan Data}

Keabsahan data yang diperoleh terutama dari hasil wawancara, dilakukan melalui teknik triangulasi. Melalui triangulasi data dicek kembali derajat kepercayaan sebagai suatu informasi. Membandingkan data hasil wawancara. Keabsahan data yang diperoleh di lapangan diperiksa dengan menggunakan teknik-teknik sebagai berikut:

1. Pertanyaan yang sama diajukan kepada informan yang berbeda melalui wawancara.

2. Observasi

3. Mengkonfirmasikan hasil temuan dengan informasi penelitian.

\section{HASIL DAN PEMBAHASAN}

\section{Hasil Penelitian}

\section{Kemampuan Awal Siswa}

Pada pertemuan awal dengan siswa dilakukan pretes sebelum dilaksanakan pembelajaran. Hasil pretes siswa diperoleh kesimpulan bahwa siswa masih tergolong kurang mampu dalam menyelesaikan soalsoal yang diajukan. Kesulitan-kesulitan siswa tersebut dapat dilihat dari kesalahankesalahan yang mereka lakukan ketika menjawab pertanyaan yang diberikan. Kriteria Tetuntasan Minimal (KKM) yang bernilai 70 dan nilai rata-rata sebesar $54,33 \%$.

\section{Pelaksanaan Pembelajaran}

\section{a. Pembelajaran Siklus I}

\section{1) Perencanaan}

Sebelum melakukan tindakan peneliti merencanakan penyusunan Rencana Pelaksanaan Pembelajaran (RPP) pada mata pelajaran IPA kelas VIII

\section{2) Tindakan}

Tindakan yang diberikan guru pada siklus I pertemuan pertama guru melakukan kegiatan sesuai dengan rencana pelaksanaan pembelajaran empat indikator yang perlu dicapai siswa, yaitu diawali dengan kegiatan pendahuluan, kegiatan inti, dan kegiatan penutup. Tindakan yang diberikan guru pada siklus I pertemuan kedua hanya melanjutkan pertemuan sebelumnya dengan tiga indikator yaitu dengan kegiatan yang terdiri dari kegiatan pendahuluan, kegiatan inti, dan kegiatan penutup. Akhir siklus I pada pertemuan kedua siswa diberikan tes hasil belajar yang bertujuan untuk melihat tingkat hasil belajar siswa setelah tindakan yang diberikan.

\section{3) Observasi}

Observasi dilakukan terhadap kegiatan atau pelaksanaan pembelajaran, dengan tujuan apakah kondisi belajar mengajar telah sesuai dengan skenario pembelajaran. Berdasarkan hasil pengamatan pada siklus I guru telah mampu melaksanakan pembelajaran sesuai dengan skenario yang telah direncanakan.

Tingkat Ketuntasan Hasil Belajar Siswa Pada Siklus I

\begin{tabular}{|c|c|c|c|}
\hline Nilai & $\begin{array}{c}\text { Jumlah } \\
\text { Siswa }\end{array}$ & Persentase & Keterangan \\
\hline 30 & 1 & $03.00 \%$ & $\begin{array}{l}\text { Belum } \\
\text { Tuntas }\end{array}$ \\
\hline 40 & 2 & $07.00 \%$ & $\begin{array}{l}\text { Belum } \\
\text { Tuntas }\end{array}$ \\
\hline 45 & 3 & $10.00 \%$ & $\begin{array}{l}\text { Belum } \\
\text { Tuntas }\end{array}$ \\
\hline 50 & 2 & $07.00 \%$ & $\begin{array}{l}\text { Belum } \\
\text { Tuntas }\end{array}$ \\
\hline 55 & 2 & $07.00 \%$ & $\begin{array}{l}\text { Belum } \\
\text { Tuntas }\end{array}$ \\
\hline 60 & 2 & $07.00 \%$ & $\begin{array}{l}\text { Belum } \\
\text { Tuntas }\end{array}$ \\
\hline 65 & 4 & $13.00 \%$ & $\begin{array}{l}\text { Belum } \\
\text { Tuntas }\end{array}$ \\
\hline 70 & 10 & $33.00 \%$ & $\begin{array}{l}\text { Telah } \\
\text { Tuntas }\end{array}$ \\
\hline 75 & 3 & $10.00 \%$ & $\begin{array}{l}\text { Telah } \\
\text { Tuntas }\end{array}$ \\
\hline 85 & 1 & $03.00 \%$ & $\begin{array}{l}\text { Telah } \\
\text { Tuntas }\end{array}$ \\
\hline \multicolumn{2}{|c|}{ Jumlah Nilai } & \multicolumn{2}{|c|}{1845} \\
\hline \multicolumn{2}{|c|}{ Jumlah siswa } & \multicolumn{2}{|c|}{30} \\
\hline \multicolumn{2}{|c|}{ Nilai rata-rata } & \multicolumn{2}{|c|}{61.50} \\
\hline \multicolumn{2}{|c|}{$\begin{array}{c}\text { Siswa yang } \\
\text { berhasil }\end{array}$} & \multicolumn{2}{|c|}{14} \\
\hline \multicolumn{2}{|c|}{$\begin{array}{c}\text { Ketuntasan } \\
\text { klasikal }\end{array}$} & \multicolumn{2}{|c|}{$47.00 \%$} \\
\hline
\end{tabular}

Berdasarkan tabel di atas terlihat bahwa terdapat 16 orang siswa $(53,00 \%)$ yang belum tuntas belajar karena memiliki tingkat keberhasilan belajar di bawah Kreteria Ketuntasan Minimal (KKM) 70, dan 
sebanyak 14 orang siswa $(47,00 \%)$ telah tuntas.

\section{4) Refleksi}

Pada siklus I, guru melakukan kegiatan pembelajaran yang terdiri dari kegiatan pendahuluan, kegiatan inti, dan penutup. Guru melakukan kegiatan pendahuluan dengan melakukan apersepsi dan motovasi, kemudian melakukan kegiatan inti dengan eksplorasi pengetahuan awal siswa.

Pembelajaran dengan model learning cycle ini terlihat 14 siswa yang tuntas belajar dan 16 siswa yang belum tuntas belajar. Hal ini dapat dilihat bahwa 14 siswa saja yang dapat menjawab tes yang diberikan. Sedangkan 16 siswa belum dapat menjawab tes dengan baik dan benar atau tuntas.

\section{b. Pembelajaran Siklus II \\ 1) Perencanaan}

Sebelum melakukan tindakan siklus II peneliti telah mengetahui kekurangan dari pembelajaran sebelumnya, oleh karea itu peneliti merancang kembali penyusunan Rencana Pelaksanaan Pembelajaran (RPP) pada mata pelajaran IPA

\section{2) Tindakan}

Pada tahap pelaksanaan tindakan pada siklus II pertemuan pertama, guru melakukan kegiatan sesuai dengan rencana pelaksanaan pembelajaran empat indikator yang perlu dicapai siswa, yang terdiri dari kegiatan pendahuluan, kegiatan inti, dan kegiatan penutup. Guru juga lebih fokus kepada pembelajaran dengan menerapkan model learning cycle yang telah dirancang untuk meningkatkan kemampuan pemahaman siswa. Kemudian sebagai bahan tes tertulis kepada siswa guru menginstruksikan siswa untuk mengumpulkan lembar pertanyaan individu yang dibagikan saat kerja kelompok berlangsung. Penilaian yang diberikan bersifat penilaian proses dengan memberikan komentar terhadap pengamatan siswa dikelompok masing-masing.

\section{3) Observasi}

Berdasarkanhasil pengamatan pada siklus II pertemuan pertama dan kedua guru telah mampu melaksanakan pembelajaran sesuai dengan skenario yang telah direncanakan. Pada akhir pertemuan siklus II dilakukan tes mengetahui perkembangan hasil belajar siswa. Tingkat ketuntasan belajar siswa pada siklus II dapat dilihat pada tabel berikut :

Tingkat Ketuntasan Hasil Belajar Siswa Pada Siklus

\begin{tabular}{|c|c|c|c|}
\hline Nilai & $\begin{array}{c}\text { Jumlah } \\
\text { siswa }\end{array}$ & Persentase & Keterangan \\
\hline 70 & 8 & $27.00 \%$ & $\begin{array}{c}\text { Telah } \\
\text { Tuntas }\end{array}$ \\
\hline 75 & 6 & $20.00 \%$ & $\begin{array}{c}\text { Telah } \\
\text { Tuntas }\end{array}$ \\
\hline 80 & 3 & $10.00 \%$ & $\begin{array}{c}\text { Telah } \\
\text { Tuntas }\end{array}$ \\
\hline 85 & 7 & $23.00 \%$ & $\begin{array}{c}\text { Telah } \\
\text { Tuntas }\end{array}$ \\
\hline 90 & 4 & $13.00 \%$ & $\begin{array}{c}\text { Telah } \\
\text { Tuntas }\end{array}$ \\
\hline 95 & 2 & $07.00 \%$ & $\begin{array}{c}\text { Telah } \\
\text { Tuntas }\end{array}$ \\
\hline $\begin{array}{c}\text { Jumlah nilai } \\
\text { Jumlah } \\
\text { siswa }\end{array}$ & \multicolumn{2}{|c|}{2395} \\
\hline $\begin{array}{c}\text { Nilai rata- } \\
\text { rata }\end{array}$ & \multicolumn{2}{|c|}{30} \\
\hline $\begin{array}{c}\text { Siswa yang } \\
\text { berhasil }\end{array}$ & \multicolumn{2}{|c|}{30} \\
\hline $\begin{array}{c}\text { Ketuntasan } \\
\text { klasikal }\end{array}$ & $100.00 \%$ \\
\hline \begin{tabular}{c} 
Berdasarkan \\
\hline
\end{tabular}
\end{tabular}

Berdasarkan tabel di atas terlihat bahwa terdapat 30 orang siswa $(100,00 \%)$ telah tuntas belajar secara klasikal dengan tingkat keberhasilan belajar 79,80 berarti tingkat keberhasilan belajar di atas melebihi Kreteria Ketuntasan Minimal (KKM) pelajaran IPA yang memiliki nilai 70 . Dengan demikian dapat diketahui bahwa hasil belajar siswa pada mata pelajaran IPA.

\section{4) Refleksi}

Pada siklus II pertemuan pertama dan kedua, guru melakukan kegiatan pembelajaran yang terdiri dari kegiatan pendahuluan, kegiatan inti, dan penutup. Berdasarkan hasil pembelajaran siklus II ini ternyata memiliki nilai rata-rata 79,83 yang melebihi Kreteria Ketuntasan Minimal (KKM) yang bernilai 70, dan sebanyak 30 siswa (100\%) tuntas belajarnya pada mata pelajaran IPA.

\section{B. Pembahasan Hasil Penelitian}

Hasil penelitian pada awal pelaksanaan pretes atau sebelum dilaksanakannya model pembelajaran learning cycle siswa memiliki nilai ratarata hasil belajar adalah sebesar 58.33 sebanayak 9 siswa yang telah tuntas belajar dan 21 siswa belum tuntas belajar. Tingkat hasil belajar ini di bawah Kreteria Ketuntasan Minimal (KKM) mata pelajaran IPA yang bernilai 70, dan juga memiliki ketuntasan klasikal sebesar $30.00 \%$, dengan demikian dapat dinyatakan bahwa tingkat ketercapaian belajar siswa belum mencapai Kreteria Ketuntasan Minimal (KKM). Selanjutnya dilakukan tindakan pembelajaran menggunakan model pembelajaran siklus belajar (learning cycle) pada siklus _ siswa 
Vol. 5, No. 2, Desember 2018

Hal : 49-53

diberi 20 soal tes yang diberikan kepada 30 siswa. nilai rata-rata hasil belajar sebesar 61,50 , jumlah siswa yang tuntas meningkat 14 siswa $(47.00 \%)$ dari 9 jumlah siswa yang tuntas pada saat pretes dan jumlah siswa yang belum tuntas sebanyak 16 siswa (53.00\%) dari 21 jumlah siswa yang belum tuntas belajar, namun tingkat ketercapaian hasil belajar siswa. sehingga perlu melakukan tindakan pembelajaran melalui siklus II.

Pada siklus II tindakan pembelajaran kembali menggunakan model pembelajaran siklus belajar (learning cycle), ditambah dengan metode ceramah, penyajian film pembelajaran, waktu yang digunakan juga ditambah, dan kelompok lebih diperkecil. Tindakan ini memberikan perubahan kepada hasil belajar siswa. Nilai rata-rata 79,83 dari $30(100 \%)$ siswa, yang sebelunya hanya 14 siswa yang tuntas pada siklus I.

Nilai rata-rata siswa pada saat dilakukan pretes atau sebelum dilakukan pembelajaran learning cycle adalah 54,33. Pada saat dilakukan siklus I dengan menggunakan pembelajaran learning cycle hasil belajar siswa pada postes siklus I meningkat mencapai nilai rata-rata 61,50 namun nilai rata-rata ini belum mencapai kreteria ketuntasan minimal. Ketuntasan klasikal sebelum dilakukan pembelajaran learning cycle mencapai $30,00 \%$, hal ini terlihat bahwa hasil belajar siswa dalam kelas VIII tersebut masih tergolong rendah, kemudian dilakukan pembelajaran menggunakan learning cycle pada siklus I, ketuntasan klasikal meningkat mencapai $47,00 \%$, maka dilakukan siklus II dengan menggunakan pembelajaran learning cycle yang mencapai ketuntasan klasikal sebesar $100.00 \%$.

\section{KESIMPULAN}

Berdasarkan hasil penelitian dan pembahasan, maka kesimpulan penelitian ini adalah

1. Hasil belajar siswa pada mata pelajaran IPA sebelum dilaksanakan model pembelajaran 54,33 dengan jumlah siswa yang tuntas sebanyak $9(30.00 \%)$ siswa dan siswa yang belum tuntas sebanyak $21(70.00 \%)$ siswa.

2. Hasil belajar siswa pada mata pelajaran IPA setelah dilakukan model pembelajaran siklus belajar (learning cycle) pada siswa kelas VIII SMP N 1 Silangkitang ialah pada siklus I nilai ratarata siswa sebesar 61,50 jumlah siswa yang tuntas sebanyak $14(47,00 \%)$ siswa dan siswa yang belum tuntas sebanyak
$16(53.00 \%)$ siswa. Sedangkan pada siklus II nilai rata-rata siswa sebesar 79.83 jumlah siswa yang tuntas 30 siswa (100\%).

\section{UCAPAN TERIMAKASIH}

Puji dan syukur kami hadiratkan kepada Allah SWT yang telah memberikan kesehatan dan waktu kepada kami sehingga dapat menyelesaikan penelitian dan laporan penelitian ini.

Ucapan terimakasih saya ucapkan kepada kepada pihak sekolah yaitu SMP N 1 Silangkitang yang telah memberikan ijin kepada saya untuk melaksanakan penelitian di sekolah tersebut.

\section{DAFTAR PUSTAKA}

Arikunto, Suharsimi, Penelitian Tindakan Kelas VIII, Bandung: Bumi Aksara, 2006

Aqib, Zainal, dkk. Penelitian Tindakan Kelas VIII, Bandung: Yahama Widya, 2009

Dimyanti dan Mudjiono, Belajar dan Pembelajaran,Jakarta: Rineka Cipta, 2008

Djumhana, Nana, Model Pembelajaran IPA di Sekolah Menengah Pertama, Direktorat Jendral Pendidikan Islam, 2007

Gredler, Margaret, E, Learning and Intruction, Terj. Tri Wibowo, Jakarta: Kencana,2011

Hamalik, Oemar, Proses belajar mengajar, Bandung: Bumi Aksara, 2008

Masganti, Perkembangan Peserta Didik, Medan: Perdana Publishing, 2010

Miarso, Yusufhadi, Menyemai Benih Teknologi Pendidikan, jakarta: kencana, 2015

Moleong, Lexy. J, Metodologi Penelitian Kulitatif, Bandung: Remaja Rosdakarya, 2000

Mulyati, Psikologi Belajar, yogyakarta: andi, 2005

Nasution, S, Metode Penelitian Naturalistik Kualitatif, Bandung: Alfabeta, 2000

Slameto, Belajar Dan Faktor-Faktor Yang Mempengaruhinya, Jakarta: Rineka Cipta, 2005

Slavin, E. Robert, Psikologi Pendidikan Jilid 2, Jakarta: Indeks, 2009. 